Canadian Journal of Physiology and Pharmacology

Volume 65, Number 4, April 1987

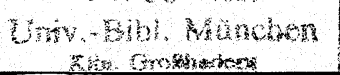

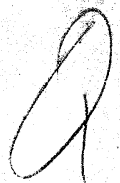

Journal canadien de physiologie et pharmacologie

Volume 65, numéro 4, avril 1987

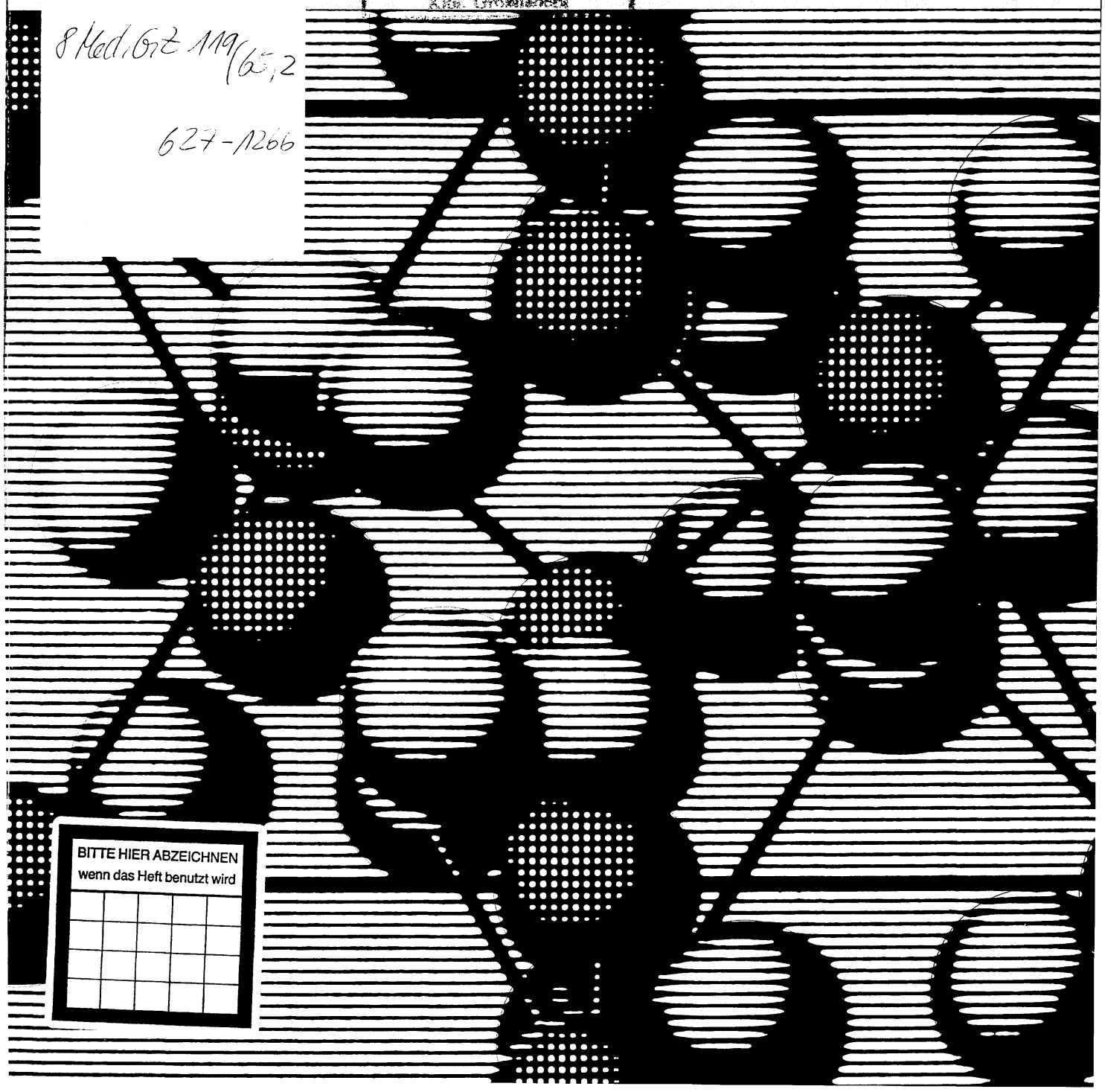




\section{Canadian Journal of Physiology and Pharmacology}

\section{An International Journal}

Published by

THE NATIONAL RESEARCH COUNCIL OF CANADA

\section{Journal canadien de physiologie et pharmacologie}

\author{
Une revue internationale
}

Bibliothek München
Publié par

LE CONSEIL NATIONAL DE RECHERCHES DU CANADA
Editors HAROLD L. ATWOOD Directeurs scientifiques KHEM H. JHAMANDAS

Assistant Editors JAMES F. BRIEN Directeurs scientifiques adjointes

Assistant to the Editors MRS. LYNDA HENDRICKSON Adjointe aux directeurs scientifiques

Associate Editors/Directeurs scientifiques associés
T. M. BRAY (Guelph)
M. E. BROSNAN (St. John's)
S. M. CAIN (Birmingham, AL)
J. R. G. CHALLIS (London)
J. CIRIELLO (London)
M. A. COOK (London)
L. DESCARRIES (Montréal)
J. DIAMOND (Vancouver)
P. E. DRESEL (Halifax)
D. O. Foster (Ottawa)
C. V. GREENWAY (Winnipeg)
M. L. HALPERIN (Toronto)
S. HEISLER (Québec)
P. D. HRDINA (Ottawa)
T. INABA (Toronto)
N. L. JONES (Hamilton)
P.-A. LAvole (Montréal)
J. P. LUND (Montréal)
G. W. MAINWOOD (Ottawa)
J. R. MCNEILL (Saskatoon)
J. MORISSET (Sherbrooke)
M. E. MORRIS (Toronto)
J. P. MORTOLA (Montréal)
R. I. OGILVIE (Toronto)
G. A. QUAMME (Vancouver)
J. M. RADZIUK (Montréal)
K. W. RENTON (Halifax)

K. RUF (Halifax)

J. SAWYNOK (Halifax)

D. L. SEVERSON (Calgary)

A. B. R. THOMSON (Edmonton)

J. V. TYBERG (Calgary)

B. B. VIRGO (Windsor)

P. WALKER (Ottawa)

M. YOUNES (Winnipeg)

\section{PUBLISHING DEPARTMENT SERVICE DE PUBLICATION}

at the National Research Council of Canada du Conseil national de recherches du Canada
Editor-in-chief
C. T. BISHOP
Directeur général

Assistant Editor-in-chief

P. A. REDHEAD

Directeur général adjoint

Manager

B. E. DREW

Directrice administrative

Assistant Manager S. D. PRUDHOMME Directeur administratif adjoint

Publishing Supervisor B. KIESSLING Chef des publications

Publication Officers S. R. STRAHLENDORF Agentes de publication M. M. CASAL

Manuscripts for publication should be submitted to the Editors, Canadian Journal of Physiology and Pharmacology, Room 513, Botterell Hall, Queen's University, Kingston, Ontario, Canada K7L 3N6. Editorial office: (613) 545-6335. Facsimile transceiver No.: (613) 545-6336.

Correspondence concerning accepted manuscripts and corrected proofs should be sent to Research Journals, National Research Council of Canada Ottawa, Ont., Canada K1A 0R6. Telephone enquiries should be directed to Mrs. B. Kiessling (613-993-9096)

Reprints may be purchased at the time of publication (an order form is sent out with the galley proof). All orders should be sent back with the galley proofs to Research Journals, National Research Council of Canada, Ottawa, Ont., Canada K1A 0R6.

Instructions to Authors are published once a year, in the first issue of each volume. Copies may be obtained from the Publishing Department of the journal.

The publisher grants permission to individuals who wish to quote short excerpts and reproduce figures, tables, or photographs from articles in this journal, provided that the source of such material is fully acknowledged. As a courtesy the consent of authors of such material should be obtained.
Manuscrits-Les auteurs doivent adresser leurs manuscrits aux Directeurs Scientifiques, Journal canadien de physiologie et pharmacologie, Room 513, Botterell Hall, Queen's University, Kingston, Ontario, Canada K7L 3N6. Bureau de la rédaction: (613) 545-6335. Télécopieur: (613) 545-6336.

La correspondance ayant trait aux manuscrits acceptés et les épreuves corrigées doivent être envoyées aux Journaux de la recherche scientifique, Conseil national de recherches du Canada, Ottawa (Ont.), Canada K1A 0R6. On peut obtenir des renseignements en téléphonant à Mme. B. Kiessling (613-993-9096).

Tirages à part-Les tirés à part peuvent être achetés au moment de la publication. Un bon de commande à cet effet accompagne les épreuves de galée et doit être retourné avec celles-ci aux Journaux de la recherche scientifique, Conseil national de recherches du Canada, Ottawa (Ont.), Canada K1A OR6.

Recommandations aux auteurs sont publiées une fois par année dans le premier numéro de chaque volume. On peut s'en procurer une copie, sur demande, au Service de publication.

L'éditeur accorde aux particuliers la permission de citer de brefs extraits et de reproduire des figures, des tableaux ou des photos dans les articles de la revue, à la condition que la source soit indiquée explicitement. Dans ce cas, il convient, par courtoisie, d'obtenir le consentement des auteurs. (c) National Research Council of Canada 1987. World rights reserved. Authorization to photocopy items for internal or personal use, or the internal or personal use of specific clients, is granted by the National Research Council of Canada for libraries and other users registered with the Copyright Clearance Center (CCC) Transactional Reporting Service, provided that the base fee of $\$ 3.00$ per copy is paid directly to CCC, 21 Congress Stroet, Salem, Massachusetts, U.S.A. 01970. $0008-4212 / 87 \$ 3.00+0.00$

The above permission does not extend to other kinds of copying, such as copying for general distribution, for advertising, or promotional purposes, for creating new collective works, or for resale. For such copying, arrangements must be made with the publisher.

\begin{abstract}
- Conseil national de recherches du Canada 1987. Tous droits réservés.
Le Conseil national de recherches du Canada acconde l'autorisation de photocopier des documents pour un usage interne ou personnel, ou pour l'utilisation interne ou personnelle de clients particuliers, aux bibliotheques et autres utilisateurs inscrits au Copyright Clearance Center (CCC) Transactional Reportin Service, a la condition que le tarif de base de 3 \$ par copie soit paye directement au Centre, au 21 Congress Street, Salem, Massachusetts, U.S.A. 01970. 0008-4212/87 3,00 \$ + 0,00.

La présente permission ne s'applique pas à d'autres genres de reproduction, notamment la reproduction en vue d'une distribution générale, à des fins de publicité ou de promotion, pour la création de nouveaux travaux collectifs, ou pour la revente. Dans ces cas, il faut prendre les dispositions qui s'imposent en
communiquant avec l'éditeur.
\end{abstract}

This journal is indexed or abstracted in: / Ce journal est signalé ou résumé dans:

Index Medicus; Nutrition Abstracts; Chemical Abstracts; Current Contents; Science Citation Index; Excerpta Medica; Biological Abstracts; International Cancer Research Data Bank 


\title{
Cellular mechanisms of potassium homeostasis in the mammalian nervous system ${ }^{1}$
}

\author{
P. GRafe ${ }^{2}$ and K. Ballanyi \\ Physiologisches Institut, Universität München, Pettenkoferstraße 12, D-8000 München 2, Federal Republic of Germany
}

Received July 21,1986

\begin{abstract}
Grafe, P., and Ballanyi, K. 1987. Cellular mechanisms of potassium homeostasis in the mammalian nervous system. Can. J. Physiol. Pharmacol. 65: 1038-1042.

Double-barrelled ion-sensitive microelectrodes were used to measure changes in the intracellular activities of $\mathrm{K}^{+}, \mathrm{Na}^{+}$, and $\mathrm{Cl}^{-}\left(a \mathrm{~K}_{\mathrm{i}}, a \mathrm{Na}_{\mathrm{i}}, a \mathrm{Cl}_{\mathrm{i}}\right)$ in neurones of rat sympathetic ganglia and in glial cells of slices from guinea-pig olfactory cortex. In sympathetic neurones, carbachol and $\gamma$-aminobutyric acid (GABA) produced a reversible decrease of $a \mathrm{~K}_{\mathrm{i}}$. The decrease of $a \mathrm{~K}_{\mathrm{i}}$ during carbachol was accompanied by a rise of $a \mathrm{Na}_{\mathrm{i}}$, whereas in the presence of GABA decreases of $a \mathrm{~K}_{\mathrm{i}}$ and $a \mathrm{Cl}_{\mathrm{i}}$ were seen. The reuptake of $\mathrm{K}^{+}$released during the action of carbachol was completely blocked by ouabain, whereas furosemide inhibited the $a \mathrm{~K}_{\mathrm{i}}$ recovery after the action of GABA. In glial cells, in contrast to the observations in the sympathetic neurones, $a \mathrm{~K}_{\mathrm{i}}$ and $a \mathrm{Cl}_{\mathrm{i}}$ increased, whereas $a \mathrm{Na}_{\mathrm{i}}$ decreased when neuronal activity was enhanced by repetitive stimulation of the lateral olfactory tract. It was found that barium ions and ouabain strongly reduced the activity-related rise of intraglial $a \mathrm{~K}_{\mathrm{i}}$ in slices of guinea-pig olfactory cortex. These data show that mammalian neurones as well as glial cells possess several $\mathrm{K}^{+}$uptake mechanisms that contribute to potassium homeostasis. Ouabain, furosemide, and $\mathrm{Ba}^{2+}$ are useful pharmacological tools to separate these mechanisms.
\end{abstract}

Grafe, P., et Ballanyi, K. 1987. Cellular mechanisms of potassium homeostasis in the mammalian nervous system. Can. J. Physiol. Pharmacol. 65 : 1038-1042.

On a utilisé des microélectrodes à double branche, sensibles aux ions pour déterminer les variations des activités intracellulaires $\mathrm{K}^{+}, \mathrm{Na}^{+}$et $\mathrm{Cl}^{-}\left(a \mathrm{~K}_{\mathrm{i}}, a \mathrm{Na}_{\mathrm{i}}, a \mathrm{Cl}_{\mathrm{i}}\right)$ dans des neurones des ganglions sympathiques de rat et dans des cellules gliales de tranches de cortex olfatif de cobaye. Dans les neurones sympathiques, le carbachol et l'acide $\gamma$-aminobutyrique (GABA) provoquèrent une diminution réversible d' $a \mathrm{~K}_{\mathrm{i}}$. La diminution d' $a \mathrm{~K}_{\mathrm{i}}$ en présence de carbachol fut accompagnée d'une élévation d' $a \mathrm{Na}_{\mathrm{i}}$, alors qu'en présence de GABA, on observa des diminutions d' $a \mathrm{~K}_{\mathrm{i}}$ et d' $a \mathrm{Cl}_{\mathrm{i}}$. La réabsorption de $\mathrm{K}^{+}$libéré durant l'action du carbachol fut complètement bloquée par l'ouabaïne, alors que le furosémide inhiba le rétablissement d'a $\mathrm{K}_{\mathrm{i}}$ après l'action de GABA. Dans les cellules gliales, contrairement aux observations dans les neurones sympathiques, $a \mathrm{~K}_{\mathrm{i}}$ et $a \mathrm{Cl}_{\mathrm{i}}$, augmentèrent, alors qu' $a \mathrm{Na}_{\mathrm{i}}$ diminua lorsque l'activité neuronale fut augmentée par la stimulation répétée du pédoncule olfactif latéral. On a constaté que les ions baryum et l'ouabaïne réduisaient fortement l'élévation reliée à l'activité de l'a $a \mathrm{~K}_{\mathrm{i}}$ intragliale dans les tranches de cortex olfactif de cobaye. Ces résultats montrent que les neurones et les cellules gliales de mammifèrent possèdent plusieurs méchanismes d'absorption de $\mathrm{K}^{+}$qui contribuent à l'homéostasie potassique. L'ouabaïne, le furosémide et le $\mathrm{Ba}^{2+}$ sont des éléments pharmacologiques utiles pour distinguer ces mécanismes.

[Traduit par la revue]

\section{Introduction}

Enhanced neuronal activity in the central nervous system is accompanied by transient elevations in the extracellular $\mathrm{K}^{+}$ activity $\left(a \mathrm{~K}_{e}\right)$ (Somjen 1979; Nicholson 1981; Sykova 1983). The rise of $a \mathrm{~K}_{\mathrm{e}}$ is the consequence of $\mathrm{K}^{+}$released from neurones via voltage- or $\mathrm{Ca}^{2+}$-dependent, transmitter-gated, and leaky $\mathrm{K}^{+}$channels. Mammalian neurones possess at least two mechanisms for $\mathrm{K}^{+}$reuptake. One is the ouabain-sensitive $\mathrm{Na}^{+}-\mathrm{K}^{+}$pump, which can be activated, for example, by the acetylcholine-induced rise in the intracellular $\mathrm{Na}^{+}$activity and the other one is a furosemide-sensitive, $\mathrm{Na}^{+}$-dependent $\mathrm{KCl}$ cotransport, which is activated during the action of $\gamma$ aminobutyric acid (GABA) (Ballanyi et al. 1984; Ballanyi and Grafe 1985).

Glial cells, on the other hand, accumulate $\mathrm{K}^{+}$during an increase of $a \mathrm{~K}_{\mathrm{e}}$ (literature reviewed by Walz and Hertz 1983). However, the mechanisms of $\mathrm{K}^{+}$uptake into glial cells are not yet understood in detail. Several factors such as spatial buffering (Orkand et al. 1966; Dietzel et al. 1982; Coles and Orkand 1983; Gardner-Medwin 1983), $\mathrm{Na}^{+}-\mathrm{K}^{+}$pump activity (Kukes et al. 1976; Walz and Hertz 1982; Grisar et al. 1983), KCl cotransport (Kimelberg and Frangakis 1985; Walz and Hinks 1985), or the presence of $\mathrm{Ba}^{2+}$-sensitive $\mathrm{K}^{+}$channels (Walz et al. 1984) have

\footnotetext{
${ }^{1}$ This paper was presented at the Ion-selective Microelectrodes and Excitable Tissue Symposium (Toronto, Ontario, July 8-11, 1986), a Satellite Symposium of the 30th IUPS Congress, and has undergone the Journal's usual peer review.

${ }^{2}$ Author to whom correspondence should be addressed.
}

been proposed to contribute to the $\mathrm{K}^{+}$uptake process. Recently, we have used double-barrelled ion-sensitive microelectrodes to measure changes in the intracellular activities of $\mathrm{K}^{+}, \mathrm{Na}^{+}$, and $\mathrm{Cl}^{-}\left(a \mathrm{~K}_{\mathrm{i}}, a \mathrm{Na}_{\mathrm{i}}, a \mathrm{Cl}_{\mathrm{i}}\right.$, respectively) in glial cells of slices from guinea-pig olfactory cortex during repetitive stimulation of the lateral olfactory tract (Ballanyi et al. 1987). These experiments showed that $\mathrm{Ba}^{2+}$ and ouabain are useful pharmacological tools to study the mechanisms underlying the $\mathrm{K}^{+}$uptake in glial cells.

The present paper reviews our intracellular measurements with ion-sensitive microelectrodes from mammalian neurones and glial cells. The data are summarized in a model about cellular mechanisms contributing to the $\mathrm{K}^{+}$homeostasis in the mammalian nervous system.

\section{Methods}

Sympathetic neurones

Experiments were performed on neurones of superior cervical ganglia of rats. Ganglia were isolated, desheathed, and continuously superfused at $30^{\circ} \mathrm{C}$ in a recording chamber (Ballanyi and Grafe 1985) with a solution containing (in $\mathrm{mM}$ ): $\mathrm{NaCl}, 118 ; \mathrm{KCl}, 4.8, \mathrm{NaHCO}_{3}$. 2.5; $\mathrm{KH}_{2} \mathrm{PO}_{4}, 1.2 ; \mathrm{MgSO}_{4}, 1.2 ; \mathrm{CaCl}_{2}, 2.5 ;$ and glucose, 10 .

\section{Cortical glial cells}

Experiments were performed on slices of the olfactory cortex of guinea pigs. After decapitation, the brain was rapidly removed and surface slices (approximately $500 \mu \mathrm{m}$ thick) were cut using a plastic guide and a bow cutter. Slices were placed in a perspex chamber (vol. 2 $\mathrm{mL}$ ) and superfused at $25^{\circ} \mathrm{C}$ with a solution of the following composition (in $\mathrm{mM}$ ): $\mathrm{NaCl}, 118 ; \mathrm{KCl}, 3 ; \mathrm{NaHCO}_{3}, 25 ; \mathrm{NaH}_{2} \mathrm{PO}_{4}$, 1.2; $\mathrm{MgCl}_{2}$. $1.0 ; \mathrm{CaCl}_{2}, 1.5$; and glucose, 10 (equilibrated with $95 \% \mathrm{O}_{2}-5 \% \mathrm{CO}_{2}$; $\mathrm{pH}$ 7.4). Drugs were added to the superfusion fluid. Cortical neurones 
sympathetic neurone
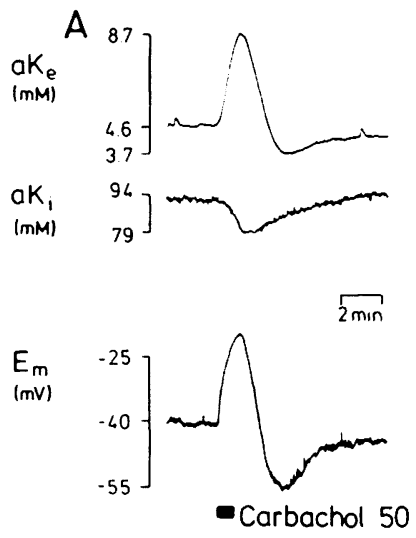

$B$
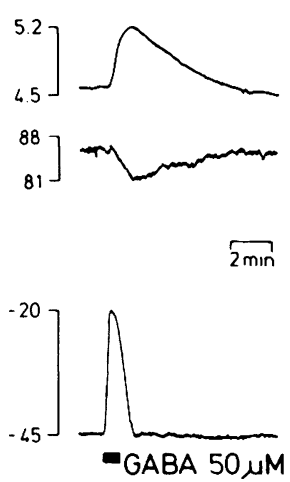

cortical glial cell

C
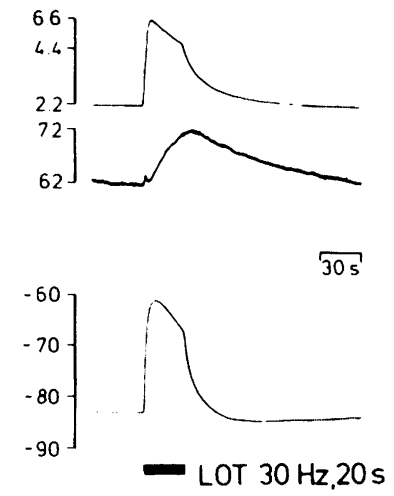

FIG. 1. An overview of changes in membrane potential $\left(E_{\mathrm{m}}\right)$ and in intra- and extra-cellular $\mathrm{K}^{+}$activity $\left(a \mathrm{~K}_{\mathrm{i}}, a \mathrm{~K}_{\mathrm{e}}\right.$, respectively) accompanying the actions of carbachol, GABA, and repetitive stimulation on neurones and glial cells. (A and B) Experiments with isolated rat sympathetic ganglia. (C) An experiment with a guinea-pig olfactory cortex slice. For further discussion see text. LOT, lateral olfactory tract.

were activated by electrical stimulation of the lateral olfactory tract with platinum wire electrodes.

\section{Ion-sensitive microelectrodes}

The properties and the methods used for the construction and calibration of double-barrelled ion-sensitive microelectrodes are described in detail elsewhere (Grafe et al. 1985; Ballanyi et al. 1987). The ligands used for the $\mathrm{K}^{+}-\mathrm{Cl}^{-}$, and $\mathrm{Na}^{+}$-sensitive microelectrodes were Corning 477317, IE-170 (WP-Instruments), and Fluka 71176, respectively. All values of intracellular $\mathrm{Na}^{+}, \mathrm{K}^{+}$, and $\mathrm{Cl}^{-}$are given in activities (Meier et al. 1980). Intracellular impalements were achieved by means of a piezo-driven micromanipulator (built by $\mathrm{M}$. Frankenberger, Munich).

\section{Results}

Intracellular $\mathrm{K}^{+}$activity in mammalian neurones and glial cells

Figure 1 summarizes observations from experiments in which intracellularly and extracellularly positioned $\mathrm{K}^{+}$-sensitive microelectrodes were used simultaneously. Parts A and B are from experiments on rat sympathetic ganglia. One can see that both carbachol and GABA depolarize the membrane of sympathetic neurones. This effect is accompanied in each case by a rise of $a \mathrm{~K}_{\mathrm{e}}$ and a decrease of $a \mathrm{~K}_{\mathrm{i}}$. The post-carbachol $\mathrm{K}^{+}$reuptake is accompanied by an undershoot of $a \mathrm{~K}_{\mathrm{e}}$ and membrane hyperpolarization. Neither phenomenon occurs after the end of the GABA application. This indicates that two different mechanisms might contribute to the $a \mathrm{~K}_{\mathrm{i}}$ recovery after carbachol and GABA. This conclusion was confirmed by pharmacological observations: ouabain blocked completely the post-carbachol $a \mathrm{~K}_{\mathrm{e}}$ recoveries, whereas furosemide inhibited the $\mathrm{K}^{+}$reuptake after the action of GABA (Ballanyi et al. 1984).

In contrast to the neurones, glial cells of guinea-pig olfactory cortex accumulate $\mathrm{K}^{+}$during a period of enhanced neuronal activity. Figure $1 \mathrm{C}$ illustrates that stimulation of the lateral olfactory tract $(30 \mathrm{~Hz}, 20 \mathrm{~s})$ resulted in a glial depolarization of about $20 \mathrm{mV}$ during an increase of $a \mathrm{~K}_{\mathrm{e}}$ of about $4 \mathrm{mM}$ (Ballanyi et al. 1987). During the depolarization $a \mathrm{~K}_{\mathrm{i}}$ increased by about $10 \mathrm{mM}$.

\section{Activity-related changes of intraglial ion activities}

The base-line level of $a \mathrm{~K}_{\mathrm{i}}$ as measured in 12 cells with a mean membrane potential $\left(E_{\mathrm{m}}\right)$ of $-84.4 \pm 3.3 \mathrm{mV}$ was $65.9 \pm 6.6$ $\mathrm{m} M$ (mean $\pm \mathrm{SD})$. Therefore a close correspondence between the calculated $E_{\mathrm{K}}$ of $-85.6 \mathrm{mV}\left(a \mathrm{~K}_{\mathrm{e}}\right.$ at rest $\left.=2.2 \mathrm{mM}\right)$ and the glial $E_{\mathrm{m}}$ is revealed. Intraglial $a \mathrm{Na}_{\mathrm{i}}$ had a resting level of $25.2 \pm$
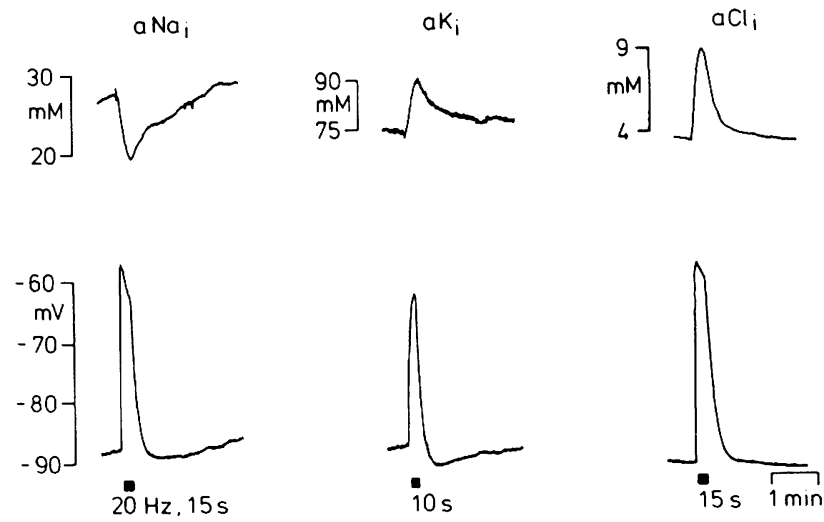

FIG. 2. Changes of intraglial ion activities during repetitive stimulation of the lateral olfactory tract $(20 \mathrm{~Hz}$ for $10-15 \mathrm{~s})$. The figure combines recordings from three different glial cells in which a $\mathrm{K}^{+}$-, $\mathrm{Na}^{+}-$, or $\mathrm{Cl}^{-}$-sensitive microelectrode was used to record changes of these ion activities in a glial cell. For a quantitative analysis of such recordings see text.

$4.6 \mathrm{mM}\left(E_{\mathrm{m}}=-83.0 \pm 2.8 \mathrm{mV} ; n=12\right)$ and the corresponding $a \mathrm{Cl}_{\mathrm{i}}$ was $6.0 \pm 1.5 \mathrm{mM}\left(E_{\mathrm{m}}=-86.9 \pm 3.8 \mathrm{mV} ; n=23\right.$; calculated under the assumption of a pure $\mathrm{Cl}^{-}$selectivity of the $\mathrm{Cl}^{-}$-sensitive ligand). Figure 2 illustrates how the intracellular activities of these ions changed when the lateral olfactory tract was stimulated repetitively $(20 \mathrm{~Hz})$ for $10-15 \mathrm{~s}$. The average rise of $a \mathrm{~K}_{\mathrm{i}}$ was $16.1 \pm 6.1 \mathrm{mM}$ (12 glial cells), $a \mathrm{Na}_{\mathrm{i}}$ decreased by $6.0 \pm 1.9 \mathrm{mM}(n=12)$, and $a \mathrm{Cl}_{i}$ increased by $6.0 \pm 1.5 \mathrm{mM}$ $(n=23)$. In conclusion, these observations demonstrate that activity-related glial $\mathrm{K}^{+}$accumulation is accompanied by a rise of intraglial $a \mathrm{Cl}_{\mathrm{i}}$ and by a fall of $a \mathrm{Na}_{\mathrm{i}}$.

\section{$\mathrm{K}^{+}$uptake mechanisms in cortical glial cells}

To differentiate between several possible mechanisms of $\mathrm{K}^{+}$ uptake into cortical glia, the action of $\mathrm{Ba}^{2+}$ was explored. Barium ions are known to block $\mathrm{K}^{+}$channels (Hille 1984) and have been previously used as a tool to differentiate between passive and active $\mathrm{K}^{+}$uptake mechanisms in skeletal muscle fibres (Sjodin and Ortiz 1975). These ions are also known to interfere with the $\mathrm{K}^{+}$homeostasis of cultured glial cells (Walz et al. 1984). In our experiments, three clear effects of $\mathrm{Ba}^{2+}$ on the glial cells were observed: (i) $\mathrm{Ba}^{2+}$ induced a membrane depolarization and led to a change from a $\mathrm{K}^{+}$-induced membrane 


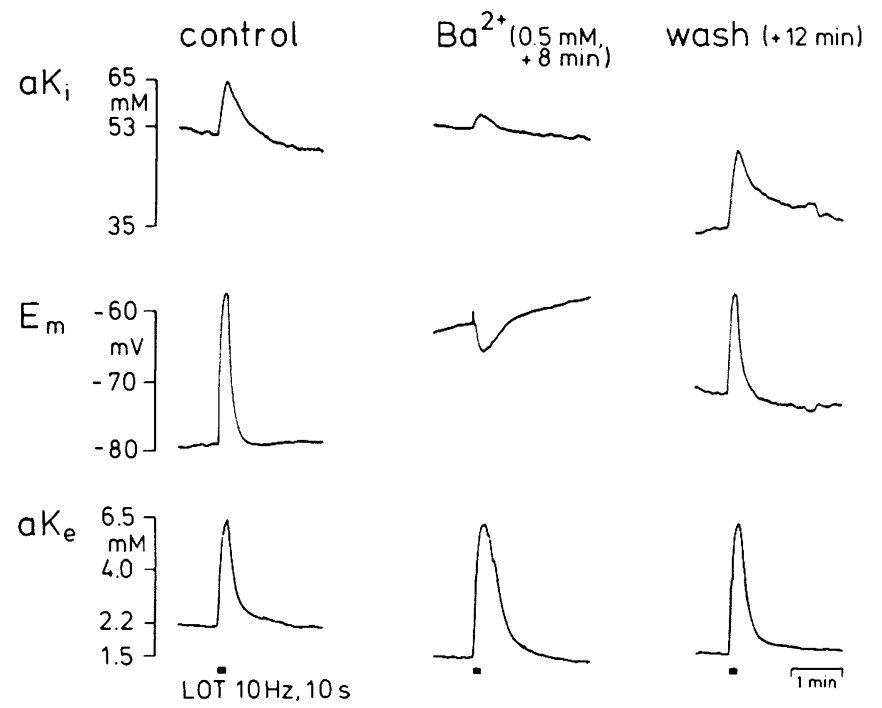

FIG. 3. Effects of barium on stimulus-induced increases in intracellular $\mathrm{K}^{+}$activity $\left(a \mathrm{~K}_{\mathrm{i}}\right)$, extracellular $\mathrm{K}^{+}$activity $\left(a \mathrm{~K}_{\mathrm{e}}\right)$, and glial membrane potential $\left(E_{\mathrm{m}}\right)$. The figure shows three sections taken from a continuous recording from a single glial cell. The left column shows the typical rise of $a \mathrm{~K}_{\mathrm{i}}$ during a stimulus-induced increase of $a \mathrm{~K}_{\mathrm{e}}$ in normal solution. In the presence of $\mathrm{Ba}^{2+}(0.5 \mathrm{mM}$, central column) an even greater rise in $a \mathrm{~K}_{\mathrm{e}}$ led to a much smaller increase of $a \mathrm{~K}_{\mathrm{i}}$ and was accompanied by a membrane hyperpolarization. Right column shows changes with stimulation during the recovery from $\mathrm{Ba}^{2+}$. LOT, lateral olfactory tract. (From Ballanyi et al. 1987, reprinted with kind permission of The Physiological Society.)

depolarization into a $\mathrm{K}^{+}$-induced hyperpolarization, (ii) $\mathrm{Ba}^{2+}$ raised the intraglial $a \mathrm{~K}_{\mathrm{i}}$ base-line level and partially blocked the $\mathrm{K}^{+}$uptake, and (iii) $\mathrm{Ba}^{2+}$ completely blocked the rise of intraglial $a \mathrm{Cl}_{\mathrm{i}}$ usually seen during a stimulus-induced rise of $a \mathrm{~K}_{\mathrm{e}}$. These effects are illustrated in Figs. 3, 4, and 5.

Figure 3 shows three excerpts from a continuous recording from a single cortical glial cell. The left column illustrates that in the normal bathing solution a membrane depolarization and a rise of $a \mathrm{~K}_{\mathrm{i}}$ occur during repetitive stimulation of the lateral olfactory tract. The center column shows a stimulation period with the same stimulus parameters $8 \mathrm{~min}$ after $\mathrm{Ba}^{2+}(0.5 \mathrm{mM})$ was added to the bathing solution. The glial cell is now depolarized and responds with a hyperpolarization to the rise of $a \mathrm{~K}_{\mathrm{e}}$. Now, only a small elevation of $a \mathrm{~K}_{\mathrm{i}}$ is seen during the stimulation period. The right column is from a period $12 \mathrm{~min}$ after $\mathrm{Ba}^{2+}$ was replaced by the normal bathing solution and shows that the effect of $\mathrm{Ba}^{2+}$ is reversible.

Figure 4 is an example of experiments in which the mechanism of the stimulus-related glial hyperpolarization was explored. The left column and center column show changes in the membrane potential and $a \mathrm{~K}_{\mathrm{i}}$ in the normal bathing solution and $12 \mathrm{~min}$ after $\mathrm{Ba}^{2+}$ was added to this solution (see Fig. 3). The membrane depolarization during the application of $\mathrm{Ba}^{2+}$ can be explained by a reduced $\mathrm{K}^{+}$conductance. A reduced efflux of $\mathrm{K}^{+}$from the glial cell in the presence of an active $\mathrm{Na}^{+}-\mathrm{K}^{+}$ pump then results in an increase of $a \mathrm{~K}_{\mathrm{i}}$ (see also Fig. 8 in Ballanyi et al. 1987). The right column is from a period $15 \mathrm{~min}$ after ouabain $(5 \mu \mathrm{M})$ was added to the $\mathrm{Ba}^{2+}$-containing bathing solution. Ouabain blocked both the stimulus-related remaining rise of $a \mathrm{~K}_{\mathrm{i}}$ and the membrane hyperpolarization. This indicates that an electrogenic $\mathrm{Na}^{+}-\mathrm{K}^{+}$pump underlies the membrane hyperpolarization and also the $\mathrm{Ba}^{2+}$-resistant $\mathrm{K}^{+}$uptake. (Ouabain did not block the stimulus-induced rise in $a \mathrm{~K}_{\mathrm{e}}$; on the

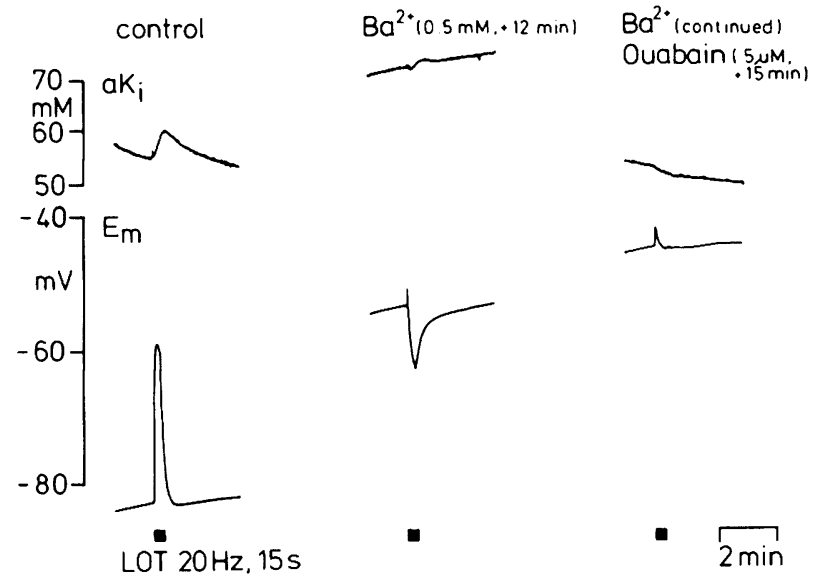

Fig. 4. Effects of barium and ouabain on stimulus-induced increases in intracellular $\mathrm{K}^{+}$activity $\left(a \mathrm{~K}_{\mathrm{i}}\right)$ and glial membrane potential $\left(E_{\mathrm{m}}\right)$. The left column shows the typical rise of $a \mathrm{~K}_{\mathrm{i}}$ during a stimulus-induced depolarization of the glial cell. In the presence of $\mathrm{Ba}^{2+}(0.5 \mathrm{mM})$ an elevation of the $a \mathrm{~K}_{\mathrm{i}}$ base-line level, smaller increase of $a \mathrm{~K}_{\mathrm{i}}$, and stimulus-induced membrane hyperpolarization were seen. The $\mathrm{Ba}^{2+}$ resistant rise of $a \mathrm{~K}_{\mathrm{i}}$ and the membrane hyperpolarization were completely blocked 15 min after ouabain $(5 \mu M)$ was added to the $\mathrm{Ba}^{2+}$ containing solution. LOT, lateral olfactory tract.

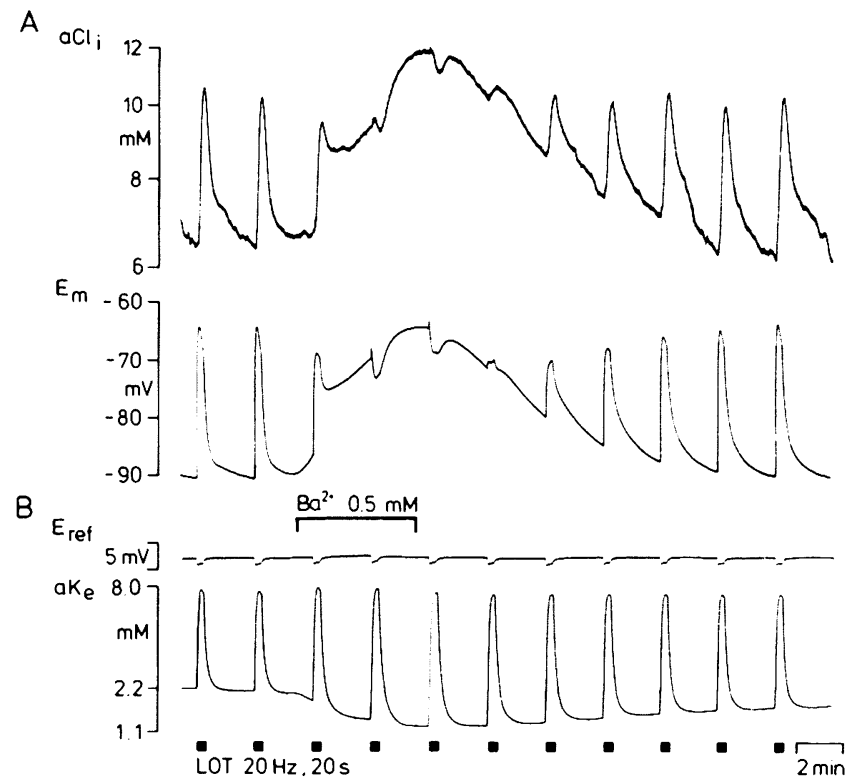

FIG. 5. Effects of barium on intracellular $\mathrm{Cl}^{-}$activity $\left(a \mathrm{Cl}_{\mathrm{i}}\right)$ and extracellular $\mathrm{K}^{+}\left(a \mathrm{~K}_{\mathrm{e}}\right)$. After two control stimulation trains, $\mathrm{Ba}^{2+}(0.5$ $\mathrm{m} M$ ) was added to the bathing solution. The typical glial depolarization in $\mathrm{Ba}^{2+}$ was accompanied by an increase in $a \mathrm{Cl}_{\mathrm{i}}$ base-line. The $\mathrm{Ba}^{2+}$ induced shift of stimulus-related depolarization into hyperpolarization was mirrored by a shift from an increase in $a \mathrm{Cl}_{i}$ to a decrease. After the washout of $\mathrm{Ba}^{2+}$, the membrane potential $\left(E_{\mathrm{m}}\right)$ as well as $a \mathrm{Cl}_{\mathrm{i}}$ recovered to base-line values. LOT, lateral olfactory tract. (From Ballanyi et al. 1987, reprinted with kind permission of The Physiological Society.)

contrary, the stimulus-related rise of $a \mathrm{~K}_{\mathrm{e}}$ was slightly bigger than usual; see Fig. 6 in Ballanyi et al. 1987.)

The behaviour of intraglial $a \mathrm{Cl}_{\mathrm{i}}$ in the presence of $\mathrm{Ba}^{2+}$ indicates a high $\mathrm{Cl}^{-}$conductance of the glial membrane. In the experiment illustrated in Fig. 5, a Cl${ }^{-}$-sensitive microelectrode was used to record $a \mathrm{Cl}_{\mathrm{i}}$ and $E_{\mathrm{m}}$ of a glial cell (Fig. 5A), whereas $\mathrm{a} \mathrm{K}^{+}$-sensitive microelectrode was positioned extracellularly to measure $a \mathrm{~K}_{\mathrm{e}}$ (Fig. 5B). Two stimulus trains in normal solution 


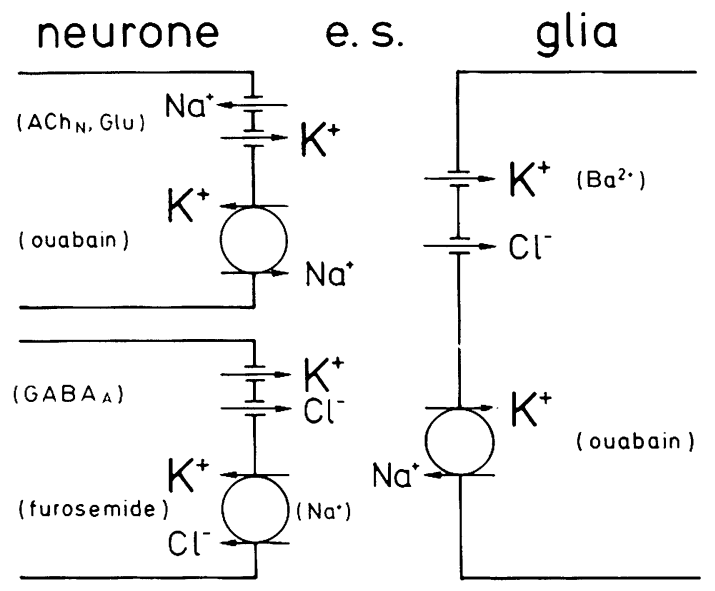

FIG. 6. Summary of $\mathrm{K}^{+}$uptake mechanisms in mammalian neurones and glia. After a rise of neuronal $a \mathrm{Na}_{i}$ via the opening of nicotinic cholinergic $\left(\mathrm{ACh}_{\mathrm{N}}\right)$ or glutamate $(\mathrm{Glu})$ receptors, the $\mathrm{Na}^{+}-\mathrm{K}^{+}$pump restores the intracellular $\mathrm{K}^{+}$activity. If neurones release $\mathrm{K}^{+}$together with $\mathrm{Cl}^{-}$(during a depolarizing action of GABA), a furosemidesensitive, $[\mathrm{Na}]_{\mathrm{e}}$-dependent $\mathrm{K}^{+}-\mathrm{Cl}^{-}$cotransport is found to maintain the normal $a \mathrm{~K}_{\mathrm{i}}$ resting level. Our results indicate that glial cells also possess at least two types of $\mathrm{K}^{+}$uptake mechanisms. There is passive $\mathrm{K}^{+}$uptake via $\mathrm{Ba}^{2+}$-sensitive $\mathrm{K}^{+}$channels (together with passive uptake of $\mathrm{Cl}^{-}$) and also the activation of a glial $\mathrm{Na}^{+}-\mathrm{K}^{+}$pump secondary to a rise of extracullular $\mathrm{K}^{+}$(see also text). e.s., extracellular space.

at the beginning of this recording revealed the stimulus-related rise of $a \mathrm{~K}_{\mathrm{e}}$, membrane depolarization and accompanying rise of $a \mathrm{Cl}_{\mathrm{i}}$ usually seen in the glial cells. $\mathrm{Ba}^{2+}$ was added to the bathing solution and within a few minutes the membrane depolarized by more than $20 \mathrm{mV}$ and $a \mathrm{Cl}_{\mathrm{i}}$ increased to about 12 $\mathrm{m} M$. Repetitive stimulation of the lateral olfactory tract during $\mathrm{Ba}^{2+}$ induced a small membrane hyperpolarization and a slight fall in $a \mathrm{Cl}_{\mathrm{i}}$. Therefore, the increase in resting $a \mathrm{Cl}_{\mathrm{i}}$, as well as the stimulus-related decrease of $a \mathrm{Cl}_{i}$, clearly indicates the close relationship between the membrane potential and $a \mathrm{Cl}_{i}$. If $a \mathrm{Cl}_{i}$ were to follow changes in $a \mathrm{~K}_{\mathrm{e}}$, then the $\mathrm{Ba}^{2+}$-induced increase of the $a \mathrm{~K}_{\mathrm{e}}$ base-line and the stimulus-related $a \mathrm{~K}_{\mathrm{e}}$ increase should have altered $a \mathrm{Cl}_{\mathrm{i}}$ in the opposite direction. Previously in the literature pertaining to glia, results from two kinds of experiment led to the conclusion that glial cells do not have a significant $\mathrm{Cl}^{-}$conductance. First, no change in glial membrane potential was seen during the transition from a high to a low extracellular $\mathrm{Cl}^{-}$medium. This fact may be explained by a lack of $\mathrm{Cl}^{-}$conductance. However, if intracellular $\mathrm{Cl}^{-}$were to leave the cell as rapidly as the decrease of $a \mathrm{Cl}_{3}, E_{\mathrm{Cl}}$ would always remain close to $E_{\mathrm{m}}$; there would be no potential change in spite of a $\mathrm{Cl}^{-}$conductance (see Fig. 4 in Ballanyi et al. 1987). Secondly, some authors did not observe changes in glial input resistance in $\mathrm{Cl}^{-}$-free extracellular medium. These experiments should be repeated with the substitution of bigger anions, in view of the discovery of large anion-conducting channels in glial cells (Gray and Ritchie 1985).

\section{Discussion}

Figure 6 summarizes our data obtained with intracellular ion-sensitive microelectrodes from rat sympathetic neurones and guinea-pig cortical glial cells. Neurones, on the one hand, exchange intracellular $\mathrm{K}^{+}$with $\mathrm{Na}^{+}$if an increase in $\mathrm{Na}^{+}$ conductance leads to a membrane depolarization. A ouabainsensitive $\mathrm{Na}^{+}-\mathrm{K}^{+}$pump restores both ion concentration gradients involved, and this electrogenic reuptake is accompanied by a membrane hyperpolarization and an undershoot of $a \mathrm{~K}_{\mathrm{e}}$. Examples of such a situation are shown by the action of glutamate on frog spinal motoneurons (Sonnhof et al. 1976) and of carbachol (via stimulation of nicotinic acetylcholine receptors) on rat sympathetic ganglia (Ballanyi et al. 1984). If, on the other hand, neurones are depolarized as a consequence of an increase in $\mathrm{Cl}^{-}$conductance (for example by the activation of $\mathrm{GABA}_{\mathrm{A}}$ receptors), both $\mathrm{Cl}^{-}$and $\mathrm{K}^{+}$are released from the cell. It was found that in such a situation an electroneutral, $\mathrm{Na}^{+}$-dependent, and furosemide-sensitive $\mathrm{K}^{+}-\mathrm{Cl}^{-}$carrier is involved in the neuronal $\mathrm{K}^{+}$homeostasis (Ballanyi and Grafe 1985).

Glial cells also have at least two mechanisms to take up $\mathrm{K}^{+}$ (Ballanyi et al. 1987). One component is a ouabain-sensitive $\mathrm{Na}^{+}-\mathrm{K}^{+}$pump that, in contrast to neurones, is activated by excess extracellular $\mathrm{K}^{+}$. The electrogenic pump current of this transport mechanism is normally short-circuited by the high resting conductance of the glial membrane. However, a ouabain-sensitive membrane hyperpolarization can be seen in the presence of $\mathrm{Ba}^{2+}$ (see Figs. 3 and 4). The $\mathrm{Na}^{+}-\mathrm{K}^{+}$pump most probably contributes to the decrease of intraglial $a \mathrm{Na}_{\mathrm{i}}$ which is observed during a rise of $a \mathrm{~K}_{\mathrm{e}}$, although other factors may contribute to this phenomenon.

The other mechanism, by which glial cells take up $\mathrm{K}^{+}$, is a $\mathrm{Ba}^{2+}$-sensitive $\mathrm{K}^{+}$conductance. This finding, together with the observation of a high $\mathrm{Cl}^{-}$conductance of the glial cells (see Fig. 5 ), indicates that the $\mathrm{K}^{+}$uptake can occur via a mechanism suggested by Boyle and Conway (1941) and Hodgkin and Horowicz (1959) to explain passive uptake of $\mathrm{K}^{+}$into muscle fibres. These authors point out that during an elevation of $a \mathrm{~K}_{\mathrm{e}}$, the presence of a $\mathrm{Cl}^{-}$conductance will prevent $E_{\mathrm{m}}$ from reaching the new $E_{\mathrm{K}}$. Hence $\mathrm{K}^{+}$(as well as $\mathrm{Cl}^{-}$) can continue to flow into the cell. Our data are compatible with this view. Another mechanism by which $\mathrm{K}^{+}$uptake could occur through $\mathrm{Ba}^{2+}$-sensitive channels would be via spatial buffer currents (Orkand et al. 1966; Coles and Orkand 1983; Gardner-Medwin 1983; Dietzel et al. 1982). According to this view, $\mathrm{K}^{+}$would enter the glial syncytium through $\mathrm{K}^{+}$channels as a result of a spatial potential gradient along the membrane of the electrically coupled glia; the rise of intraglial $a \mathrm{Cl}_{\mathrm{i}}$ would be explained by a redistribution of $\mathrm{Cl}^{-}$ions within the linked glial cells. Our experiments do not exclude such a mechanism. However, the existence of a passive $\mathrm{KCl}$ uptake would allow the $\mathrm{K}^{+}$to be stored in the glial cell in the immediate neighbourhood of the active neurone, where it might be more readily available to the neurone during recovery from $\mathrm{K}^{+}$loss (Gray and Ritchie 1985).

\section{Acknowledgements}

We thank Professor G. ten Bruggencate for constant encouragement and helpful discussions during the course of this project. Miss G. Schneider and Mrs. C. Müller provided expert technical and secretarial assistance. The work was supported by the Deutsche Forschungsgemeinschaft (SFB 220).

Ballanyi, K., and Grafe, P. 1985. An intracellular analysis of $\gamma$-aminobutyric-acid-associated ion movements in rat sympathetic neurones. J. Physiol. (London), 365: 41-58.

Ballanyi, K., Grafe, P., Reddy, M. M., and ten Bruggencate, G. 1984. Different types of potassium transport linked to carbachol and GABA actions in rat sympathetic neurons. Neuroscience $(\mathrm{Ox}-$ ford), 12: 917-927.

Ballanyi, K., Grafe, P., and ten Bruggencate, G. 1987. Ion activities and potassium uptake mechanisms of glial cells in guineapig olfactory cortex slices. J. Physiol. (London). 382: 159-174. 
Boyle, P. J., and Conway, E. J. 1941. Potassium accumulation in muscle and associated changes. J. Physiol. (London), 100: 1-63.

Coles, J. A., and ORKand, R. K. 1983. Modification of potassium movement through the retina of the drone (Apis mellifera) by glial uptake. J. Physiol. (London), 340: 157-174.

Dietzel, I., HeinemanN, U., Hofmeier, G., and Lux, H. D. 1982. Stimulus-induced changes in extracellular $\mathrm{Na}^{+}$and $\mathrm{Cl}^{-}$concentration in relation to changes in the size of the extracellular space. Exp. Brain Res. 46: 73-84.

Gardner-Medwin, A. R. 1983. Analysis of potassium dynamics in mammalian brain tissue. J. Physiol. (London), 335: 393-426.

Grafe, P., Ballanyi, K., and ten Bruggencate, G. 1985. Changes of intracellular free ion concentrations, evoked by carbachol or GABA, in sympathetic neurons. In Ion measurements in physiology and medicine. Edited by Kessler, M., Harrison, D. K., and Höper, J. Springer, Berlin, Heidelberg, New York. pp. 184-188.

GraY, P. T. A., and Ritchie, J. M. 1985. Ion channels in Schwann and glial cells. Trends Neurosci. 8: 411-415.

Grisar, T., Franck, G., and Delgado-Escueta, A. V. 1983. Glial contribution to seizure: $\mathrm{K}^{+}$activation of $\left(\mathrm{Na}^{+}, \mathrm{K}^{+}\right)$-ATPase in bulk isolated glial cells and synaptosomes of epileptogenic cortex. Brain Res. 261: 75-84.

Hille, B. 1984. Ionic channels of excitable membranes. Sinauer Associates Inc., Sunderland, MA.

HodgKIN, A. L., and Horowicz, P. 1959. The influence of potassium and chloride ions on the membrane potential of single muscle fibres. J. Physiol. (London), 148: 127-160.

KimelberG, H. K., and Frangakis, M. V. 1985. Furosemide- and bumetanide-sensitive ion transport and volume control in primary astrocytes from rat brain. Brain Res. 361: 125-134.

KuKes, G., Elul, R., and DE Vell.is, J. 1976. The ionic basis of the membrane potential in a rat glial cell line. Brain Res. 104: 71-92.

Meier, P. C., Ammann, D., Morf, W. E., and Simon, W. 1980. Liquid-membrane ion-sensitive electrodes and their biomedical ap- plications. In Medical and biological applications of electrochemical devices. Edited by Koryta, J. J. Wiley \& Sons Ltd., New York. pp. 13-91.

NicHOLSON, C. 1981. Brain-cell microvenvironment as a communication channel. In The neurosciences-Fourth study program. Edited by Schmitt, F. O., and Worden, F. G. MIT Press, Cambridge, U.S.A. pp. 457-476.

ORKAND, R. K., Nicholls, J. G., and KUfFler, S. W. 1966. Effect of nerve impulses on the membrane potential of glial cells in the central nervous system of Amphibia. J. Neurcphysiol. 29: 788-806.

SJodin, R. A., and OrTIZ, O. 1975. Resolution of the potassium ion pump in muscle fibers using barium ions. J. Gen. Physiol. 66: 269-286.

SOMJEN, G. G. 1979. Extracellular potassium in the mammalian central nervous system. Annu. Rev. Physiol. 41: 159-177.

Sonnhof, U., Grafe, P., and KruminiKL, J. 1976. Interaction of glutamate with the sodium pump in spinal motoneurons of the frog. Pfluegers Arch. 362: R34.

SYKOVA, E. 1983. Extracellular $\mathrm{K}^{+}$accumulation in the central nervous system. Prog. Biophys. Mol. Biol. 42: 135-190.

Walz, W., and Hertz, L. 1982. Ouabain-sensitive and ouabainresistant net uptake of potassium into astrocytes and neurons in primary cultures. J. Neurochem. 39: 70-77.

1983. Functional interactions between neurones and astrocytes. II. Potassium homeostasis at the cellular level. Prog. Neurobiol. 20: 133-183.

WALZ, W., and HINKS, E. C. 1985. Carrier-mediated $\mathrm{KCl}$ accumulation accompanied by water movements is involved in the control of physiological $\mathrm{K}^{+}$levels by astrocytes. Brain Res. 343: 44-51.

Walz, W., Shargool, M., and Hertz, L. 1984. Barium-induced inhibition of $\mathrm{K}^{+}$transport mechanisms in cortical astrocytes-its possible contribution to the large $\mathrm{Ba}^{2+}$ evoked extracellular $\mathrm{K}^{+}$signal in brain. Neuroscience (Oxford), 13: 945-949. 